\section{Decolonisation starts}

in a name: Moving

on from the colonial

pretence that 'Maori'

or 'indigenous peoples'

are explanatory frames
Political Science

$1-19$

(C) The Author(s) 2016

Reprints and permissions: sagepub.co.uk/journalsPermissions.nav DOI: I0.II77/00323 I87|6675654 pnz.sagepub.com

@SAGE

\author{
Lindsey Te Ata o Tu MacDonald
}

\begin{abstract}
This article examines why and how scholars should acknowledge and name each of the diverse political actors and institutions that typically are objectified as 'indigenous peoples' on the global stage, or 'Maori' in New Zealand. For instance, rather than suggesting a political relationship or conflict exists between 'Maori and the Crown', political scientists and theorists should name the political actors and political institutions for which Maori is a shorthand, for example, 'Te Runanga o Ngai Tahu (the corporate entity of the Ngai Tahu whanui) and the Committee of Tuahiwi Marae disagreed with the Crown'. A variety of reasons are discussed as to why this objectification of Maori (and any other indigenous population) as a single political actor has occurred, the problems are pointed out, and a range of examples are given. Not every use of the terms 'Maori', 'indigenous peoples' or similar descriptors in political science stands in for a specific political actor (e.g. sometimes, it is suggesting a cleavage or a group at whom a policy is directed), but where scholars are describing or suggesting political action, they should be careful in their use of ethnic labels. I suggest that it would be more productive to study the specific contexts, intentions and actions of individuals and institutions that might consider indigeneity as being part of their identity.
\end{abstract}

\title{
Keywords
}

Agency, decolonisation, indigenous politics, indigenous self-determination, Maori, tino rangatiratanga

\footnotetext{
Corresponding author:

Lindsey Te Ata o Tu MacDonald, Department of Political Science and International Relations, University of Canterbury, Private Bag 4800, Christchurch, 8I40, New Zealand.

Email: lindsey.macdonald@canterbury.ac.nz
} 


\section{Introduction'}

For several decades now, scholars within political science and political theory have taken it upon themselves to champion the cause of indigenous peoples. ${ }^{2}$ However, I have noticed that among the work attempting to assist indigenous peoples in their decolonisation efforts, there is missing a detailed and large political science and theory of the politics of indigenous institutions and individuals; more typically, the claims of political science on behalf of indigenous peoples are based on their difference, not on an analysis of their politics. I suggest that political science scholars need to prove - not take for granted - that identity is important for the particular political action that they claim is 'indigenous'. I explore in the article a variety of examples in which 'indigenous' is presumed to give intention to, or otherwise gets in the way of, the analysis of political actors who may be claiming their indigenous identity as part of their reason for their arguments or actions. Finally, I suggest that decolonisation begins for political science and theory with a refusal to treat indigenous populations as a single political actor, and by treating the indigenous political authorities that represent or claim to represent parts of those populations as units of analysis whose claims to representation and uses of power need study and analysis. ${ }^{3}$

1. I would like to thank the audience at the New Zealand Political Science Conference 2013, Maria Bargh, Kirsty Gover and Dominic O'Sullivan for their encouragement and feedback on this article.

2. For example: Jeff Corntassel, 'From Rights to Responsibilities: Rethinking Indigenous Peoples' Citizenship and Self-Determination Strategies', conference paper (2008); Susan Dodds, 'Citizenship, Justice and Indigenous Group-Specific Rights - Citizenship and Indigenous Australia', Citizenship Studies, Vol. 2, No. 1 (1998): 105-119; Shin Imai, 'Indigenous Self-Determination and the State', Indigenous Peoples and the Law: Comparative and Critical Perspectives, (Oxford, Hart Publishing, 2009); Jacob T. Levy, The Multiculturalism of Fear (Oxford and New York, NY: Oxford University Press, 2000); Ulf Mörkenstam, 'Recognition as if Sovereigns? A Procedural Understanding of Indigenous Self-Determination', Citizenship Studies, Vol. 19, Nos 6-7 (2015): 634-48; Alfred Taiaiake, Peace, Power, Righteousness: An Indigenous Manifesto (Toronto: Oxford University Press, 1999).

3. The distinction I am making between a population and political actors is similar to one that Tim Rowse has noted occurs in Australian political discourse. On the one hand, there is a concern with distributive justice that drives a focus on the socio-economic outcomes of the indigenous Australian 'population', and, on the other hand, there is a concern for a broader social justice conception which suggests that the institutions of the indigenous 'peoples' of Australia receive recognition in the Constitution. Rowse argues, in ways that parallel my argument, that a focus on the indigenous 'population' obscures recognition of the political agency and institutions of indigenous 'peoples'. I thank an anonymous reviewer for the reference. Tim Rowse, Rethinking Social Justice: From 'Peoples' to 'Populations' (Canberra: Aboriginal Studies Press, 2012). 


\section{The analytical yoke of history}

Historically, the failure of political science to treat indigenous political institutions as units of political analysis is quite strange since political science and the decolonisation movement, with its myriad indigenous political actors, have grown side by side. As political science emerged from its history discipline yoke, so, too, did many countries grapple and remove their colonial yoke. Political science, then, has evolved, documented and studied the global processes of decolonisation in tandem with its growth as a scholarly pursuit. For example, much of political development and modernisation literature, particularly that focused on Latin America, Asia and Africa, is about the development of decolonised polities. Yet, political science continues to look upon indigenous political actors and group them as 'indigenous people', without differentiating and examining indigenous polities and other sites of political action of indigenous decolonisation. It even, typically, continues the colonial trope of calling the indigenous political institutions 'tribes', even where those tribal formations are now billion-dollar corporate entities in settler states from New Zealand to Canada. There are even many fascinating historical and contemporary examples of attempts by indigenous political actors to decolonise that political science or theory could study. For instance, in New Zealand, the arguments for decolonisation were made by indigenous political actors at least as early as the first formalisation of the colonial process itself. Two examples are Rewa of Kororāreka's comments rejecting the British Crown's offer of the Treaty of Waitangi and in support of Iwi governance during the 1840 Treaty debates, ${ }^{4}$ and Wiremu Kingi's letters to Governor Gore Browne emphasising his chiefly authority to veto the Waitara purchase during $1859 .{ }^{5}$ Both chiefs found themselves at war with the colonial authorities, as well as the Maori allies of those authorities, for their attempts to halt or reverse the colonial process. Settlers also made comments about decolonisation, of which Sir William Martin's England and the New Zealanders $(1847)^{6}$ is perhaps the most famous. The pamphlet raised questions about how the Crown could justify its claim to political authority over New Zealand given the failure to observe the land rights of Maori. More recently, famous writings about the politics of decolonisation include Ranginui Walker's Struggle without End and Linda Smith's Decolonising Methodologies $^{7}$. Walker and Smith are explicitly conscious of their debt to Fanon's concern 'not

4. W. Colenso, The Authentic and Genuine History of the Signing of the Treaty of Waitangi, New Zealand, February 5 and 6, 1840: Being a Faithful and Circumstantial, Though Brief, Narration of Events Which Happened on That Memorable Occasion; with Copies of the Treaty (Christchurch: Govt. Printer, 1996), pp. 18-19.

5. For example, see the letter printed in Sir William Martin's pamphlet, The Taranaki Question (Auckland: Melanesian Press, 1860), pp. 29-30.

6. William Martin, England and theNewZealanders. Part I. Remarks upon a Despatch from the Right Hon. Earl Grey to Governor Grey dated Dec. 231846 (Auckland, Printed at the College Press, 1847).

7. Walker, Ranginui, Struggle without End: Ka Whawhai Tonu Matou (Auckland, N.Z.: Penguin, 1990); Smith, Linda Tuhiwai, Decolonizing Methodologies: Research and Indigenous Peoples (Zed Books, 1999). 
just to challenge the policies of expansionist governments, but to undermine the ways of thinking which perpetuate colonial social structuring within colonised societies' ${ }^{8}$ There is, then, a voluminous literature that details the hopes, or, more recently, the actuality, of Maori speaking, acting and political engaging as individuals or organisations.

The literature that describes self-determination efforts in New Zealand and elsewhere shrugs off the binary imposition of colonised and colonial, of Maori and non-Maori, such that such writing speaks not of Maori as the political actors, but of $i w i$, hapu, and whanau representatives, an officer of the army in charge of Tikanga, a performer in a kapahaka group representing a particular region, an MP who represents Te Tai Tokerau or Te Tai Tonga, or an $i w i$ fisheries officer. Indeed, the political landscape has so changed in New Zealand that individuals and institutions who may identify as Maori are so merged in the politics of government that it may be better to speak of the embedding of indigeneity in the New Zealand government. ${ }^{9}$ Instead of backing out, indigenous peoples in New Zealand seem to have explosively embedded their authority both within and without the polity, for example: there are $i w i$ deals, such as the fisheries settlement (which means that iwi now own around one-third of New Zealand's fishing quota); Ngai Tahu's position as an equal voting partner with the Crown in the rebuild of Christchurch; iwi holding significant infrastructure assets like energy businesses or telecommunications businesses, or schools; and, finally, the Maori political party, which became a critical support partner for legislation in Parliament from the moment it was registered. In sum, diverse indigenous institutions and people are finding self-determination through exerting power and influence on the New Zealand polity at all levels of government and other social organisations.

For all the active politics of decolonisation, political science as a discipline seems reluctant to join in the decolonisation process; to participate in, describe and analyse the process in which individuals who are indigenous organise and act politically, and shrug off the colonial binary in which they are seen only as 'indigenous' and therefore not able to have political power. ${ }^{10}$ I mean this in its simplest terms. Notwithstanding notable

8. David A. Lynes, 'Cultural Pain vs. Political Gain: Aboriginal Sovereignty in the Context of Decolonization', Ethnic and Racial Studies, Vol. 25, No. 6 (2002): 1052. Frantz Fanon and Richard Philcox, The Wretched of the Earth: Frantz Fanon; Translated from the French by Richard Philcox; with Commentary by Jean-Paul Sartre and Homi K. Bhabha (New York, Grove Press, 2005).

9. The characterisation of indigeneity as now embedded in government is drawn from B. Kingsbury and K. Gover (2005) 'Embedded Pluralism: Globalisation and the Reappearance of Indigenous People's Cartographies', presented at the International Conference for the Study of Political Thought (CSPT) Conference on the State, 8-10 April.

10. There are exceptions who prove the generalisation by studying and naming particular indigenous actors. See, for instance, the work of articles in this special edition and: Maria Bargh, 'Multiple Sites of Māori Political Participation', Australian Journal of Political Science, Vol. 48, No. 4 (2013): 445-455; H. Catt and M. Murphy, Sub-State Nationalism: A Comparative Analysis of Institutional Design (London: Routledge, 2002); Kirsty Gover, Tribal Constitutionalism: States, Tribes, and the Governance of Membership (Oxford and New York, NY: Oxford University Press, 2010); R.L. Madrid, 'Indigenous Parties and 
exceptions, political science worldwide and particularly in New Zealand is still imagining that the state and other political institutions see 'indigenous populations' as political actors. Yet, the brilliance of the decolonisation process, for instance, in New Zealand, is that it is now impossible to use Maori and non-Maori categories in any plausible analysis, excepting in the statistical analyses of population demographics. For example, when an institution purports to speak for 'Maori' on political issues, the result is bitterly contested by other Maori organisations, and political conflict and legal battles ensue. ${ }^{11}$ To put this idea in the language of political science, individuals and organisations that may include being Maori among important signifiers of identity are selfdetermining, and those individuals do not perform exclusively - if they ever did - as Maori. That is, these individuals who may be indigenous act in, and with, collectivities created by themselves, and those collectivities have overcome colonial authority, or at least the colonial imperative that they are Maori and are therefore without power. To now impose 'Maoriness' upon them, without specifying the political actors and examining the context and intentions of those political actors, is to profile those individuals and institutions racially, and thus imposes a colonial gaze on those who are attempting to escape colonial power.

The actors upon whom political science gazes and then analyses may, of course, take their identity as Maori very seriously. Those actors may be very concerned with their cultural values, including their Tikanga, their Whakapapa or their knowledge of Maturanga Maori. However, the behaviours of those political actors are not to assist others to imagine them as ciphers for concerns labelled 'Maori' or 'indigenous', but for personal reasons. For instance, historic settlements are made by iwi and hapu (and other entities) because the families that comprise them lost land (not because they represent 'the historic injustice that indigenous peoples have suffered'). That those peoples, like my tupuna, lost land because of racism toward indigenous peoples is horrific, but those families ask for land back not to seek an end to that racism, but because they want their land back or compensation for its unfair loss. Hapu protest about water quality not because they are Maori, but because they care about water quality. Many will enunciate these claims in diverse Maori ways, and they may do so because they have values one associates with the label 'Maori'. However, political scientists, for the most part, for reasons quite beyond me, persist in seeing these actions as signifiers of 'Maori' or 'indigenous' actions. There are, of course, similarities between the experience of indigenous populations during colonisation, and comparative politics and history has an important role in explicating those similarities. However, again, the actual political actors should be named. More pointedly, to ascribe to history and identity the intentions and actions of individuals and organisations who

Democracy in Latin America', Latin American Politics and Society, Vol. 47, No. 4 (2005): 161-179; Dominic O'Sullivan, Beyond Biculturalism: The Politics of an Indigenous Minority (Wellington: Huia Publishers, 2007); Tim Rowse, 'The Reforming State, the Concerned Public and Indigenous Political Actors', Australian Journal of Politics and History, Vol. 56, No. 1 (2010): 66-81.

11. Mihi Forbes, 'Split in Leadership of NZ Māori Council', Radio New Zealand, 20 April 2016. 
may be indigenous under the catchall phrase 'indigenous' or 'Maori' is to ascribe intention and action to a population of people who are related only by ancestry; I assume such a racialised view of intention and action is not one that social theorists or analysts would like to hold.

The fascination with categorising actions as 'Maori' or 'indigenous' via the colonial gaze obscures important political behaviours and intentions that should be analysed by political science scholars. For example, political science has little research that studies and reports on the resilience of traditional indigenous political structures that have existed over hundreds of years, such as iwi and hapu. Nor does political science scholarship have much to say about the ways in which political actors are using the various political arguments and actions available to them as indigenous individuals and organisations; rather, the discipline tends to study the statements of claims for indigenous difference. ${ }^{12}$ Moreover, when an institution or individual uses arguments that scholars might think are indigenous, or purports to represent indigenous issues in public, there is little literature or research on how to decide whether that political actor does act on behalf of those people he or she purports to represent. The implicit idea is that indigenous peoples simply can speak for indigenous issues. Put in this abstract way, it is clear that this indigenous representation is somehow immune from the demands that political scientists typically put on the legitimacy of those purporting to represent a group in politics. Again, political science sees with a colonial gaze that makes Maori 'other', 'special' or 'different', and so does little to investigate indigenous political representation beyond the Parliament. ${ }^{13}$ It seems that political science continues to act as 'the colonist who fabricated and continues to fabricate the colonized subject'. ${ }^{14}$

\section{Decolonizing the discipline}

The remedy for this colonising gaze of political science, I suggest, is to stop writing about individuals and organisations as 'indigenous', and to start using the actual names of the political actors and political institutions. My point is that the word 'indigenous', or 'Maori', is often used in political science to label a group of actors as though that label, in

12. For instance, Patrick Macklem, Indigenous Difference and the Constitution of Canada (Toronto: University of Toronto Press, 2001).

13. There is excellent and detailed work in this area, see: M.P.K. Sorrenson and Ann R. Parsonson, A History of Maori Representation in Parliament (Wellington: Royal Commission on the Electoral System - 'Towards a Better Democracy', 1986). Maria Bargh, Maori and Parliament: Diverse Strategies and Compromises (Wellington: Huia Publishers, 2010); Alexandra Xanthaki and Dominic O'Sullivan, 'Indigenous Participation in Elective Bodies: The Maori in New Zealand', International Journal on Minority and Group Rights, Vol. 16, No. 2 (2009): 181-207; Dominic O'Sullivan, 'The Treaty of Waitangi in Contemporary New Zealand Politics', Australian Journal of Political Science, Vol. 43, No. 2 (2008): 317.

14. Frantz Fanon and Richard Philcox, The Wretched of the Earth: Frantz Fanon; Translated from the French by Richard Philcox; with Commentary by Jean-Paul Sartre and Homi K. Bhabha (2007), p. 2. 
itself, is explanatory of their political actions. Indigenous individuals and institutions can choose these labels for themselves, but when a political scientist borrows that name without indicating the evidence for that use, the researcher will obscure the politics of that choice of identity: that the use of such a name is an indicator of an intra-indigenous political claim in which one group is purporting to represent all who may wish to identify as indigenous. So, to use 'indigenous' or 'Maori' in such a case is to obscure the most important and basic politics of any situation - the claim to have the power to represent a population.

For political science or philosophy, politics, as Goodin puts it, is the 'constrained use of social power'. ${ }^{15}$ So, political science has focused on the constraints, the boundaries or across boundaries, and those boundaries are most typically found in territorial states wielding a monopoly of force. The concept of indigeneity has, and continues to be, incredibly difficult to place in one of our pre-existing categories successfully. Various attempts have been made to categorise indigenous peoples as 'minority groups', 16 as 'racial or ethnic groups', ${ }^{17}$ as a 'cultural group', ${ }^{18}$ as a group who suffered 'historical injustice', ${ }^{19}$ as a 'sub-state nation', ${ }^{20}$ and others besides, none of which have proven successful at providing a plausible frame of analysis. ${ }^{21}$ The inability to create a plausible analytic category for indigenous political activity has caused major problems. For instance, it hobbled the definitions within the Declaration of the Rights of Indigenous Peoples so that many countries with large indigenous populations simply denied that those indigenous groups existed, and signed the declaration in the sure knowledge that it had no repercussions for their domestic or foreign policies. ${ }^{22}$

15. Robert E. Goodin, The Oxford Handbook of Political Science (Oxford and New York, NY: Oxford University Press, 2011), p. 5.

16. Will Kymlicka, The Rights of Minority Cultures (Oxford: Oxford University Press, 1995).

17. Thomas C. Davis, 'Patterns of Identity: Basques and the Basque Nation, Nationalism and Ethnic Politics', Nationalism and Ethnic Politics, Vol. 3, No. 1 (1997): 61-88; Shapiro, Ian, Will Kymlicka (eds.), American Society for Political and Legal Philosophy. Meeting, and Association of American Law Schools., Ethnicity and Group Rights, Nomos; 39 (New York: New York University Press, 1997).

18. Will Kymlicka, Liberalism, Community, and Culture (Oxford: Clarendon Press, 1989); Joyce Green, 'The Difference Debate: Reducing Rights to Cultural Flavours', Canadian Journal of Political Science, Vol. 33, No. 1 (2000): 133-144.

19. Janna Thompson, Taking Responsibility for the Past: Reparation and Historical Injustice (Cambridge: Blackwell Publishers and Polity, 2002).

20. H. Catt and M. Murphy, Sub-State Nationalism (London: Routledge, 2002).

21. Jeff J. Corntassel, 'Who Is Indigenous? "Peoplehood" and Ethnonationalist Approaches to Rearticulating Indigenous Identity', Nationalism and Ethnic Politics, Vol. 9, No. 1 (2003): 75-100; Benedict Kingsbury, “"Indigenous Peoples” in International Law: A Constructivist Approach to the Asian Controversy', The American Journal of International Law, Vol. 92, No. 3 (1998): 414-457.

22. For example, India, China, Algeria and Egypt all deny the existence of indigenous peoples in their territories but are signatories to the Declaration of the Rights of Indigenous Peoples. Brendan Tobin and Ebooks Corporation, Indigenous Peoples, Customary Law and Human Rights: Why Living Law Matters (Abingdon: Routledge, 2014), p. 169. 
The difficulty that indigeneity presents to political science is odd when one considers the hundreds, and, in some territories, thousands, of years that contiguous indigenous political authorities have existed. Political science has managed to invent an extensive new set of words to cope with the innovations of the European Union, but political researchers still seem to have difficulty recognising and naming the political authority of indigenous institutions, even where these institutions are, in many cases across the globe, older than the Peace of Westphalia. These entities have withstood the onset and complete domination of their territories by other political arrangements and yet have re-emerged as vibrant entities providing much to their members, confronting the state and winning back constitutional and political power. ${ }^{23}$ Surprisingly, a bibliographic review suggests that there are few political scientists who take seriously the voices of indigenous peoples such that they recognise and study the actual political aspirations of indigenous people using close qualitative or quantitative work. ${ }^{24}$ There are plenty of scholars who have subtly and interestingly examined indigenous politics while bearing in mind the subjectivity of indigenous peoples, for example, non-indigenous scholars like Tim Rowse, Paul Muldoon, Janine Hayward, Kirsty Gover or Paul McHugh, ${ }^{25}$ and indigenous scholars like Maria Bargh, Chris Anderson and Dominic O'Sullivan (to name some among a myriad). ${ }^{26}$ Then, there are other scholars for whom this question would not arise. For instance, when a government agency writes on the 'Maori economy ${ }^{27}$ or Amohia Boulton writes on Maori public health policy ${ }^{28}$ they are identifying particular

23. P.G. McHugh, 'Treaty Principles: Constitutional Relations Insider a Conservative Jurisprudence', Victoria University of Wellington Law Review (nb, no. 1), Vol. 39 (2008): 39-72.

24. Maria Bargh, 'Multiple Sites of Māori Political Participation', Australian Journal of Political Science, Vol. 48, no. 4 (2013): 445-455; Kirsty Gover, Tribal Constitutionalism: States, Tribes, and the Governance of Membership (Oxford and New York, NY: Oxford University Press, 2010); Roger C.A. Maaka, 'The New Tribe: Conflicts and Continuities in the Social Organisation of Urban Maori', The Contemporary Pacific, Vol. 6, No. 2 (1994): 311-336; Toni Michelle Sheed, Māori Political Agency: A Q Method Study of Māori Political Attitudes in New Zealand (Christchurch: University of Canterbury, 2014).

25. Respectively, Tim Rowse, 'Official Statistics and the Contemporary Politics of Indigeneity', Australian Journal of Political Science, Vol. 44, No. 2 (2009): 193; Paul Muldoon, 'Thinking Responsibility Differently: Reconciliation and the Tragedy of Colonisation', Journal of Intercultural Studies, Vol. 26, No. 3 (2005): 237-254; Gover, Tribal Constitutionalism: States, Tribes, and the Governance of Membership; Paul G. McHugh, Aboriginal Title: The Modern Jurisprudence of Tribal Land Rights (Oxford: Oxford University Press, 2011).

26. Bargh, 'Multiple Sites of Māori Political Participation'; Chris Andersen, 'Critical Indigenous Studies: From Difference to Density', Cultural Studies Review, Vol. 15, No. 2 (2009): 80-100; Dominic O'Sullivan, Beyond Biculturalism: The Politics of an Indigenous Minority (Wellington: Huia Publishers, 2007).

27. Te Puni Kokiri Ministry of Maori Development, Maori in the New Zealand Economy (Wellington: Te Puni Kokiri Ministry of Maori Development, no date).

28. Amohia Boulton, Kiri Simonsen, Tai Walker, Jacqueline Cumming, Chris Cunningham, 'Indigenous Participation in the 'New' New Zealand Health Structure', Journal of Health Services Research \& Policy, Vol. 9, suppl. 2 (2004): 35-40. 
policy concerns for the whole population, and particularly in health, 'Maori' has been proved to be a valid descriptor for government policy interventions.

Yet, as I will show in the following, there are still many writers on indigenous politics that nominalise people - a process that Billig has called the replacement of people with nouns. ${ }^{29}$ As he notes, scholars analyse and 'create things out of what people do; and then, when the analysts formulate statements of theory, they depict these things as actors, doing what people do'. ${ }^{30}$ So, multiple indigenous political actors become 'indigenous people', or multiple Maori political actors become 'Maori'. Political science seems to nominalise populations constantly, for instance, when it shortens the government of New Zealand's position in discussing international relations to simply 'New Zealand's position'. Of course, a political scientist will realise that it is the polity, the institutional political actor, to which the 'New Zealand' refers. However, when this shorthand is adopted by political scientists writing about Maori, there is an important difference. Scholars are not using 'Maori' as a shorthand for Maori political authority since the scholars are aware that there is typically no single political authority that represents Maori. Rather, scholars using 'Maori' or 'indigenous peoples' are asking us to think of 'indigenous' as the defining aspect of political behaviour, and that the whole population who could be Maori are part of that political action, rather than considering that the indigeneity may be simply one part among many (or few) of each person's identity and, importantly for political science, of the performance of that identity. As Billig notes of these big nouns like 'Maori' or 'indigenous peoples', when scholars use them:

we do not have to be clear - we do not have to think hard about what we really mean, especially when we are writing for others who regularly use these same words. In our own safe circles, where we all will be exchanging the same semantic tokens, we can leave the gap between the world and the words as wide as we want. ${ }^{31}$

The way in which this objectification of all indigenous political experience operates is - humorously - indicated by the Internet meme in Figure 1. The meme uses a photo of an indigenous person commenting on the Australian political issue of people arriving off the Australian coast in boats, noting that for boat people themselves, non-indigenous Australians seem unimpressed with the new boat people. In the meme, a photo of someone who is, or is supposed to signify, an indigenous Australian elder has superimposed over it

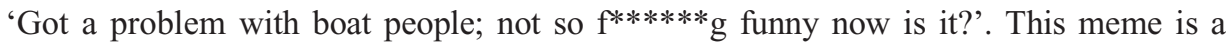
humorous take on the Australian government's policies towards boat people (given the settler majority were boat people too) until you realise that, quite probably, the indigenous man was not asked for permission to be included in this Internet meme (indeed, there is no attribution for the photo at all). ${ }^{32}$ Indeed, so easy is the idea of the caricature of the

29. Michael Billig, Learn to Write Badly: How to Succeed in the Social Sciences (Cambridge: Cambridge University Press, 2013).

30. Ibid., p. 137.

31. Ibid., p. 137.

32. The man is the famous indigenous Australian actor David Gulpilil. The photo is a still from the film Australia (2008), in which Gulpilil plays a character called 'King George'. The meme, then, works through a representation of aboriginality that is literally fictional. 


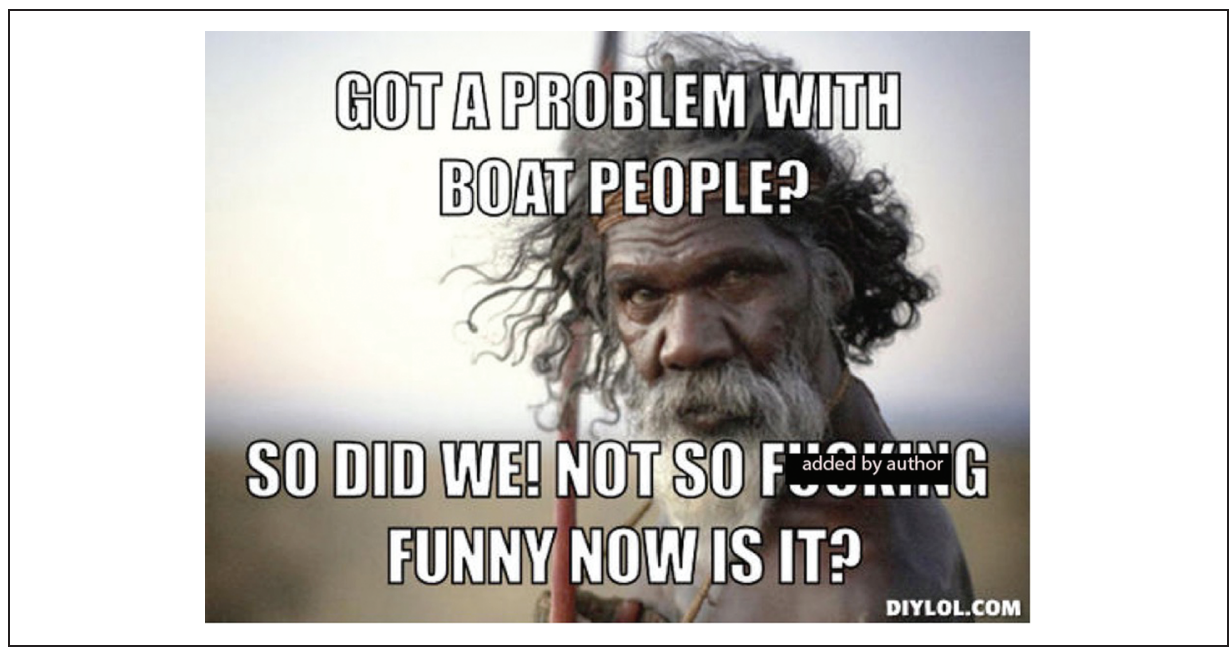

Figure I. Internet meme illustrating how quick we are to identify symbolic indigenous difference without paying attention to the politics of indigenous representation.

indigenous identity, that our first thought is not 'Who is this individual?', but rather 'this is a representation of an Indigenous Australian', and with that thought, we make that person bear the weight of other people's political opinions and become a signifier for the whole of indigenous Australia, or at least our imagined image of those peoples.

In the same way, indigenous and non-indigenous scholars have, without realising it, assumed that it is possible to create objective categories of indigenous peoples. The rest of this article examines a variety of ways in which the idea of, or the object called, 'indigenous peoples' is put to use in the service of politics, political science and political theory, or a philosophical point. In New Zealand, the most pervasive example of the use of indigenous as synonymous with all indigenous political ideas is the ubiquitous New Zealand phrase 'Maori and the Crown'. ${ }^{33}$ This phrase suggests that there is an objective Maori political authority that has power and authority that is equal with the Crown. The Crown, in the phrase, is the legal personality that combines the regulatory and administrative power of the New Zealand state and thus includes the cabinet, the prime minister and, where necessary - for signatures such as the making of war and authorising legislation - the governor general. In short, the Crown is the government of New Zealand. Originally, this phrase was used normatively by legal scholars of indigenous rights ${ }^{34}$ to suggest that Maori and the Crown should be equals. This normative idea of equality

33. Te Puni Kokiri and New Zealand Ministry of Maori Development, He Tirohanga O Kawa Ki Te Tiriti $O$ Waitangi: A Guide to the Principles of the Treaty of Waitangi as Expressed by the Courts and the Waitangi Tribunal (Wellington: Te Puni Kokiri, 2001).

34. For example, David V. Williams, 'Te Tiriti O Waitangi - Unique Relationship Between Crown and Tangata Whenua?', in I.H. Kawharu (ed.), Waitangi: Maori and Pakeha Perspectives of the Treaty of Waitangi (Auckland: Oxford University Press, 1989), pp. 64-91. 
entered the lexicon from the original Treaty jurisprudence case, ${ }^{35}$ borrowed from that lexicon of indigenous political actors, and legal cases, which imagined that indigenous peoples were in a diplomatic relationship with the states in which they resided. ${ }^{36}$ However, as a political description or analysis of the relationship between the Maori population and the New Zealand Crown, it is nonsense. It places the Crown, the political authority in charge of the New Zealand state, with the legitimating device of national elections and a monopoly of force, against a population, Maori, whose diverse political groupings are seldom in tandem, and whose political subjectivities are so different that half of the adult population chooses to be on the general roll and half on the Maori roll. The use of this phrase, either normatively or descriptively, immediately disempowers Maori as a political force, for it does not, nor cannot, describe a situation of equals unless the whole Maori population suddenly, en mass, secedes and forms a state. Even then, political scientists would talk about a Maori state (and a government that represented them) and the Crown. In actuality, for Maori, it is $i w i$ and other newly emergent $i w i$-like structures (e.g. the Urban Maori Authorities) that have the legitimacy of representation, though this is not uncontested. ${ }^{37}$ Finally, the legal origins of the phrase in actual case law provide a clear insight into the actual indigenous actors that confront the Crown: it is not 'Maori' who take the Crown to court, but political institutions like $i w i$ or the New Zealand Maori Council. ${ }^{38}$

Another of the places in which 'Maori' as a noun is used to describe political groups is in texts where the scholar presumes that Maori will support this or that cause. Maori become a monolithic ethnicity or population that the author imagines that they are supporting or helping, and who should listen to and follow the advice proffered by the expert. In this vein, Jane Kelsey suggests that neoliberalism promised self-determination to Maori but did not deliver:

35. New Zealand Maori Council v Attorney-General (lands), Case, 1 NZLR 641 (1987). For an excellent guide to the first 15 years of Treaty jurisprudence, see Te Puni Kokiri and New Zealand Ministry of Maori Development, He Tirohanga O Kawa Ki Te Tiriti O Waitangi: A Guide to the Principles of the Treaty of Waitangi as Expressed by the Courts and the Waitangi Tribunal. For a recent commentary, see Wheen, Nicola Rowan, and Janine Hayward, Treaty of Waitangi Settlements (Wellington: Bridget Williams Books, 2012).

36. For a history of indigenous representation on the global stage, see Ronald Niezen, The Origins of Indigenism: Human Rights and the Politics of Identity (Berkeley, CA: University of California Press, 2003). For a brilliant summation of this normative literature - if flawed by the typical colonial imagining of indigenous populations as coherent political actors - see Ulf Mörkenstam, 'Recognition as if Sovereigns? a Procedural Understanding of Indigenous Self-Determination', Citizenship Studies, Vol. 1025 (2015): 1-15.

37. Andrew Sharp, 'Recent Juridical and Constitutional Histories of Maori', in Andrew Sharp and P.G. McHugh (eds), Histories, Power and Loss: Uses of the Past: A New Zealand Commentary (Wellington: Bridget Williams Books, 2001).

38. For example in Te Runanga o Ngai Tahu v Attorney-General, NZLR (High Court, 2010), 1, 511 New Zealand Maori Council v Attorney-General (lands), NZLR (Court of Appeal, 1987), $1,641$. 
The new model of economic development that neo-liberalism offers to Maori empowers the same colonial state fronted by the Maori Affairs bureaucracy, to continue dictating the model of development that Maori should follow.... At the domestic level, that state's supreme authority to regulate economic, social and political life within New Zealand remains effectively unchallenged. ${ }^{39}$

As I have noted elsewhere, Kelsey is right in so far as the state's colonial control over the legal system allowed it to reform its structures in ways devastating to the socioeconomic status of Maori. ${ }^{40}$ However, the neoliberal reforms also allowed a massive flourishing of Treaty jurisprudence, as well as $i w i$ settlements and further political gains for Maori; it was only when the government started selling land that it became available for settlements. In the service of a critique of neoliberalism, Kelsey is presenting a story of 'Maori' loss; yet, for many indigenous organisations and individuals, the reforms were also part of a political landscape in which they were finally able to claim and make political authority for themselves, across the health, education and resource management sectors. To put Kelsey's argument into perspective, is it possible to replace 'Maori' in her argument with the Treaty Tribes Coalition, or Ngai Tahu, or the Urban Maori Authorities or even a single hapu? No, because then it would be obvious that she was attempting to speak on behalf of a group that should represent itself. Why, then, is it seemingly permissible for the noun 'Maori' to be used in this way?

Another example of indigenous peoples being used as an object to buttress scholarly arguments comes from the work of one of the pre-eminent non-indigenous theorists of indigenous rights, James Tully. Tully is most widely known for his advocacy of the politics of recognition, and he typically deploys the indigenous population and the historic injustice that 'they' have suffered to fortify his argument that indigenous peoples are one of the 'strange multiplicities' encountered in politics today in need of such 'recognition' ${ }^{41}$ As he puts it:

If, therefore, Locke is wrong about the nature of property and government in non-state and specifically Amerindian societies, as I have argued; and if the aboriginal peoples, the British Crown, Chief Justice Marshall, International law, and Canadian and the United States constitutional law are right in claiming that Amerindians are self-governing nations with ownership of their territories; then it follows from the central theory of government of the Two Treatises itself that they have the right to defend themselves and their property. ${ }^{42}$

39. Jane Kelsey, 'Maori, Te Tiriti, and Globalisation', in Michael Belgrave, Merata Kawharu, David V Williams, Ian H Kawharu (eds), Waitangi Revisited: Perspectives on the Treaty of Waitangi (South Melbourne: Oxford University Press, 2005), p. 98.

40. Lindsey Te Ata o Tu MacDonald and Paul Muldoon, 'Globalisation, Neo-Liberalism and the Struggle for Indigenous Citizenship', Australian Journal of Political Science, Vol. 41, No. 2 (2006): 209-223.

41. James Tully, Strange Multiplicity: Constitutionalism in an Age of Diversity, The John Robert Seeley Lectures (Cambridge and New York, NY: Cambridge University Press, 1995).

42. James Tully, An Approach to Political Philosophy: Locke in Contexts (Cambridge: Cambridge University Press, 1993), p. 175. 
Tully, as a historian of political thought, marshals ample evidence to show that the colonists neglected to observe that indigenous peoples had their own polities. In so doing, he has explained the ways in which political thought was used to justify the taking of aboriginal land and political authority in North America. However, his argument throughout the rest of his writing is that:

the theory of limited constitutional government and the rule of law of the Two treatises, and of liberal theories descended from it means that every citizen has the right to support, with force if necessary, the first nations in their constitutional struggle to bring 'arbitrary' government to abide by the 'settled, standing laws' they have been 'delegated' to uphold. ${ }^{43}$

To reconcile indigenous peoples with settler communities - and thereby avoid this forceful revolution - Tully advocates:

A democratic way to negotiate this difficult form of reconciliation that could be acceptable to both parties. [One that is] ... neither a form of recognition handed down to Indigenous peoples from the state nor a final settlement of some kind. It is an on-going partnership negotiated by free peoples based on principles they can both endorse and open to modification en passant. ${ }^{44}$

Tully cites no evidence or even a single indigenous voice to suggest that he is representing those indigenous peoples on whose behalf he is speaking in either his comprehensive statement of his political philosophy, Philosophy in a New Key, ${ }^{45}$ or in the earlier, and much quoted, Strange Multiplicity, ${ }^{46}$ excepting an attempt to suggest that he is working within a metaphor provided by a famous indigenous sculpture, the 'Spirit of Haida Gwaii', created by a Haida artist Bill Reid. Tully's brave and thorough examination of a possible way forward for politics in the 21 st century has been much commended. ${ }^{47}$ Of what meaning is his reconstruction of recognition to indigenous peoples? Perhaps more importantly, without indigenous voices, the indigenous peoples appear in his text only to represent particular kinds of injustice rather than as real historical agents making claims to or against colonial states. Political theory would be impossible if it did not caricature actors and institutions, such as when it discusses 'citizens' or 'individuals'? However, it seems to me that there is a great deal of difference between the use of a concept that could include 'anyone', such as citizenship, and making it clear with the phrase 'indigenous peoples' that those peoples are not the same as citizens and then to propose ways in which such difference should be 'reconciled' or recognised. The trouble with speaking for indigenous peoples has an analogy with feminist philosophy, where the

43. Ibid., p. 175.

44. James Tully, Public Philosophy in a New Key (vol. 1) (Cambridge: Cambridge University Press, 2008), p. 223.

45. Tully, Public Philosophy in a New Key.

46. Tully, Strange Multiplicity: Constitutionalism in an Age of Diversity.

47. The Canadian political science association awarded Public Philosophy in a New Key the C.B. Macpherson Prize for the 'best book in political theory written in English or French' in Canada 2008-2010. 
conceit of talking for others, or imagining that you can represent their needs and intentions, has been roundly condemned. ${ }^{48}$

The creation of 'indigenous peoples' as a noun, with an abstract objective existence removed from the political actors that it is supposed to model, combined with a lack of accountability for the purposes to which scholars can put this noun, leads to some peculiar rhetorical claims. Take, for example, the writing of renowned international indigenous activists and scholar Taiaike Alfred. In Peace, Power, Righteousness: An Indigenous Manifesto, he suggests that:

Aboriginal Rights are in fact the benefits accrued by indigenous peoples who have agreed to abandon their autonomy in order to enter the legal and political framework of the state. After a while, indigenous freedoms become circumscribed and indigenous rights get defined with no respect to what exists in the minds and cultures of the Native people. $^{49}$

The claim that all who seek aboriginal rights are thereby working with the state and are abandoning their true selves has its similarities with many political strategies which claim that only the writer has true vision, or insight. Political actors and writers are free to make such claims. However, scholars might expect to see some evidence that indigenous rights are, indeed, 'defined with no respect to what exists in the minds and cultures of Native people', beyond the forceful rhetoric and claims of special insight. There is no evidence provided in Peace, Power and Righteousness, though one does wonder how he would prove such a claim. If he is making claims without proof, perhaps he is writing as a representative of indigenous peoples, not as a scholar. However, Alfred speaks as though he is writing about all indigenous peoples, not just his tribe (Kahnawá: ke in the Mohawk Nation). The use of 'indigenous peoples' as objects, as a concept (and not composed of actual existing individuals who may have different political opinions), enables these grand rhetorical claims since the identification of the actual indigenous political actors (such as other aboriginal groupings in Canada) as the objects of Alfred's rhetoric would make scholars sceptical, if not outright dismissive, of Alfred's claims to representation. One more example from Alfred of the objectification of indigenous peoples comes from an article in the otherwise very proper political science journal Government and Opposition. In the article, Alfred and Corntassel suggest a series of decolonising 'mantras of a resurgent Indigenous movement', one of which is that indigenous peoples must 'decolonise their diet - our people must regain the selfsufficient capacity to provide our own food, clothing, shelter and medicines'.50 Devoid of evidence, of the stories of those who have suffered from colonisation impacting on their food, clothing, shelter and so on, this is a banal claim - all people

48. Apparently bell hooks insists that it is lower caps, so style guides suggest following her intention - ie 'bell hooks', From Margin to Center (Boston, MA: South End, 1984).

49. Taiaiake, Peace, Power, Righteousness: An Indigenous Manifesto, p. 140.

50. Taiaiake Alfred and Jeff Corntassel, 'Being Indigenous: Resurgences against Contemporary Colonialism', Government and Opposition, Vol. 40, No. 4 (2005): 597-614. 
deserve to be self-sufficient. ${ }^{51}$ The other mantras include 'Change Happens One Warrior at a Time' and 'Freedom is the Other Side of Fear'. These 'mantras and the pathways they represent will be put into practice by every person in their own way ${ }^{52}$ in the context of the particular contexts of colonialism. While one can hardly disagree with the authors that 'Indigenous pathways of authentic action and freedom struggle start with people transcending colonialism on an individual basis', ${ }^{53}$ there is no particular reason given for the mantras put forward, nor any scholarly evidence produced for any of the claims.

Many political scientists writing about indigenous peoples are much more measured, but they nevertheless use 'indigenous peoples' as a noun and presume to create a set of political ideas about them, without reference to indigenous peoples' statements, political actors or organisations. For example, in the seminal paper 'National Self-Determination', Margalit and Raz attempt 'to identify groups by those characteristics which are relevant to the justification of the right [to self-government] ${ }^{54}$ The authors assess a list of claims to self-determination to find out whether 'a moral case can be made in support of national self-determination'. ${ }^{55}$ These reasons include a group having a common culture, growing up in that culture, being recognised by others as a member of that group and so on. Margalit and Raz's sensitive contribution to the debate over claims of self-determination by groups such nationalist minorities (including, in their view, indigenous political actors) was one of the first attempts to make arguments for self-determination for sub-national populations from philosophical first principles. For all the philosophical sophistication and subtlety, however, I wonder where the voices of the political actors who use, or might make use of, these claims might be. Margalit and Raz are glossing over a century of nationalist claims - including indigenous claims - for self-determination. Globally, indigenous representatives have spoken about their need for self-determination in all countries in which they exist, and at various international forums, for many years. ${ }^{56}$ Those efforts appear nowhere in the text of the article.

51. Diet has had major political significance in both history and contemporary politics for indigenous peoples. See, for instance, chapter 10 of Bringing them Home: Report of the National Inquiry into the Separation of Aboriginal and Torres Strait Islander Children from Their Families (Sydney: Human Rights and Equal Opportunity Commission, 1997), or any history of the colonisation of Amer-Indian territory. Alfred and Corntassel reference none of these points but rather lecture indigenous people en masse about how they should behave an unsettling reproduction of the colonial behaviour described in the Bringing them Home report. I am grateful to the anonymous reviewer who asked me to substantiate my argument with Alfred and Corntassel's article.

52. Taiaiake Alfred and Jeff Corntassel, 'Being Indigenous: Resurgences against Contemporary Colonialism', Government and Opposition, Vol. 40, No. 4 (2005): p. 613.

53. Taiaiake Alfred and Jeff Corntassel, 'Being Indigenous: Resurgences against Contemporary Colonialism', Government and Opposition, Vol. 40, No. 4 (2005): p. 612.

54. Avishai Margalit and Joseph Raz, 'National Self-Determination', The Journal of Philosophy, Vol. 87, No. 9 (1990): 443.

55. Ibid., p. 440.

56. Niezen, The Origins of Indigenism: Human Rights and the Politics of Identity. 
Another measured, apparently even-handed, attempt to analyse indigenous political claims comes in Waldron's quite famous supersession thesis ${ }^{57}$ and its use of the noun 'indigenous peoples' to grievously misrepresent the claims of many indigenous political actors. His papers on the topic are known for making a devastating argument - within the bounds of philosophy - that, all other things being equal, if a government is making efforts to remove inequality, they need not attend to historic injustice that occurred several generations ago, and this is discussed using indigenous historic claims as the key example. ${ }^{58}$ In Waldron's summation, his supersession thesis suggests that 'certain things that were unjust when they occurred may have been overtaken by events in a way that means their injustice has been superseded'. ${ }^{59}$ The conclusion, which is almost implicit in his papers, is that historic settlements with $i w i$ and hapu and other indigenous peoples are wrong if the government is attempting to create distributive justice in other ways.

Philosophically, Waldron's supersession thesis is very strong because complete rectification of past indigenous injustice would require counterfactual speculation about what past individuals might or might not have done, and that would be to deny the agency of those individuals. So far, so good. Unfortunately, the argument rests on an assumption about indigenous clams that is simply wrong, and that assumption is so quickly glossed over that few have noticed just how much it exaggerates indigenous claims. For the purposes of the supersession thesis, Waldron imagines that justice for indigenous peoples is to undo colonisation such that it had never happened. This is how he phrases it:

suppose, first, that it is our aim to do justice to the legitimate grievances and claims of [indigenous] individuals in this context.... Many generations have passed since the injustice complained of took place. The best hope of reparation ... is to transform the present so that it matches as closely as possibly the way things would be now if the injustice had not occurred. ${ }^{60}$

In 20 years of researching indigenous claims, and in a very thorough study of a database of minorities across the world with claims against states, ${ }^{61}$ I have never found a statement by an indigenous political actor that they wish for everything to be returned to

57. Paul Patton, 'Historic Injustice and the Possibility of Supersession', Journal of Intercultural Studies, Vol. 26, No. 3 (2005): 255-266.

58. Jeremy Waldron, 'Historic Injustice: Its Remembrance and Supersession', in Graham Oddie and Roy W. Perrett (eds), Justice, Ethics, and New Zealand (Auckland: Oxford University Press, 1992), pp. 139-170; J. Waldron, 'Superseding Historic Injustice', Ethics, Vol. 103, No. 1 (1992): 4-28; Jeremy Waldron, 'Redressing Historic Injustice', University of Toronto Law Journal, Vol. 52, No. 1 (2002): 135-160; Jeremy Waldron, 'Settlement, Return, and the Supersession Thesis', Theoretical Inquiries in Law, Vol. 5, No. 2 (2004): 237-268.

59. Waldron, 'Settlement, Return, and the Supersession Thesis', p. 241.

60. Waldron, 'Redressing Historic Injustice', pp. 143-144.

61. See: the Minorities at Risk Data Set. College Park, MD: Minorities at Risk Project, Center for International Development and Conflict Management (CIDCM), University of Maryland. http://www.mar.umd.edu 
how it was before colonisation. Once the assumption of complete ratification is removed, all counterfactual speculation is unnecessary. That is, the claims of historic injustice by indigenous political actors are based on a wide variety of arguments, ranging from cultural loss (WAI 262), to a desire to gain compensation for illegally confiscated land (Taranaki claim), to soured deals. I understand that Waldron's aim is to explore the plausibility of some philosophical arguments about historical injustice, and, as I have mentioned, it is an interesting argument. However, my concern is that in using 'indigenous peoples' as his example, his argument does not relate in any way to the actual claims of indigenous political actors, and neither does his characterisation of their political aims relate to the truth.

Finally, we turn back to a New Zealand example of the objectification of indigenous peoples. In her groundbreaking work, Decolonizing Methodologies, Linda Smith presents an account of the ways in which it might be possible for indigenous peoples to reclaim their self-determination so that indigenous peoples might 'decolonise our minds, to recover ourselves, to claim a space in which to develop a sense of authentic humanityy ${ }^{62}$ Smith argues that this decolonisation is necessary, among other reasons, due to:

the denial by the West of humanity to Indigenous Peoples, the denial of citizenship and human rights, the denial of the right to self-determination - all these demonstrate palpably the enormous lack of respect which has marked the relations of Indigenous and non Indigenous Peoples. ${ }^{63}$

Smith's writing is brilliant and powerful. It is also a rhetorical description of a historical process that took over 200 years, in which Maori and non-Maori institutions and individuals played a myriad of complex roles. It is true that Maori and others were and are subject to racism on a day-to-day basis and that health, welfare and other social indicators display disparities between Maori and non-Maori that are awful. Yet, it is not 'the West' that has denied human rights because 'the West' is a concept, and imaginative object, a noun. As Paul McHugh has pointed out: 'Men, not law, caused the suffering of aboriginal peoples. ${ }^{64}$ Like 'The West', the concept 'indigenous peoples' hides, not exposes, those diverse stories of loss. Such phrases allow, as Billig has pointed out, the construction of nouns upon nouns, so that, in the end, the actual people who lived and suffered, and, importantly for our purposes, were and are political actors, are suppressed. In the end, such phrases allow texts that purport to be about people to remove them altogether. Billig notes that:

a particular function of social scientific jargon [is to] give the insider confidence to claim superior, radical knowledge without appearing to downgrade others; and also to claim that attacks on jargon indicate just how ignorant and conservative the attackers are. In this way, the jargon-user can act elitist while speaking radical -a handy skill in the contemporary world. ${ }^{65}$

62. Linda Tuhiwai Smith, Decolonizing Methodologies: Research and Indigenous Peoples (London: Zed Books, 1999), p. 23.

63. Ibid., p. 120.

64. McHugh, Aboriginal Title: The Modern Jurisprudence of Tribal Land Rights, p. 31.

65. Billig, Learn to Write Badly: How to Succeed in the Social Sciences, p. 92. 


\section{Conclusion}

At this point, a sceptical reader may acknowledge that indigenous peoples such as Maori are used as objects, and that this use creates ethical and analytical difficulties for scholars. However, that same reader might point out that many other populations are used likewise in texts, particularly peoples that also do not have their own state, such as the Tamils, Catalan peoples and the Inuit. Such a reader might suggest that if politics is all about engaging with the state to affect 'who gets what', and since Maori or those others are a population that could be seen as a 'who' in that definition, should political science not study how those peoples politically organise? In other words, what is wrong with the political category 'Maori' or 'indigenous people', other than the way it hides individual political actors and institutions? This is, after all, why Margalit and Raz have theorised the categories and justifications that should - in their eyes - make a state think that an indigenous population is qualified or justified in being a rightful claimant of selfdetermination rights. It is also the logic behind Kelsey's arguments; Maori should (though she automatically assumes that her argument is descriptive rather than normative, so I have replaced the 'will' with 'should') be fearful and antagonistic towards free trade, and thus form a voting bloc or political movement against policy that liberalises New Zealand. Likewise, Tully and Alfred are putting forward normative arguments about what indigenous peoples should (or might wish to) do. So, the reader might wonder what exactly is wrong with characterising indigenous peoples, or even Maori, in this way. For instance, Maori and other indigenous peoples could just choose not to take the advice of the political arguments of the various authors. However, to make use of the story that Bishop Desmond Tutu used to illustrate the moral absurdity of apartheid: let us replace black (or indigenous) and white (or non-indigenous) with the descriptors 'short noses' and 'long noses'. ${ }^{66}$ It would be absurd if political scientists described all the political institutions and actors who had short noses as 'short nose peoples'. Likewise, pretending that 'indigenous peoples' are a single political actor akin to a state or a government makes as much sense as analysing the political self-determination of the minority short nose population in a state that is composed of a majority of long noses. That is, indigenous qua indigenous does not make a political actor, but rather a population. Scholars have long ago stopped talking about women as a single political actor; perhaps it is time to do that honour to indigenous individuals and the institutions to which they choose to belong.

Finally, there is an ethical problem with the scholars mistaking indigenous populations for their political actors - it denies and subsumes the particularity and history of their stories, replacing them with a generic population-based story. In New Zealand, for instance, indigenous political actors, such as whanau, hapu and iwi, have a history of representation that stretches beyond the written word, and this history is much older than universal - or even all male - suffrage in New Zealand. To subsume those ancient and resilient entities under the label 'Maori' or 'indigenous peoples' merely reproduces the colonial gaze that first refused those political authorities and actors their

66. Desmond Tutu, The Rainbow People of God (New York: Juta and Company Ltd, 2006), p. 163. 
right to self-determine. Let us stop repeating that mistake. It may be a small and quiet change, but refusing to politicise an entire population for our scholarly purposes is nevertheless a vital first step in the decolonisation process for political science. By taking the time to identify the indigenous political actors about whom political scientists speak, indigenous individuals and institutions would be acknowledged as selfdetermining, and scholars' reductive colonial gaze would now be able to see - and research - the plethora of post-colonial political behaviour by indigenous political actors that is directly in front of them.

\section{Declaration of Conflicting Interests}

The author(s) declared no potential conflicts of interest with respect to the research, authorship and/or publication of this article.

\section{Funding}

The author(s) received no financial support for the research, authorship and/or publication of this article.

\section{Author biography}

Lindsey Te Ata o Tu MacDonald (Ngai Tahu) is a Lecturer in the Department of Political Science and International Relations at the University of Canterbury. 